
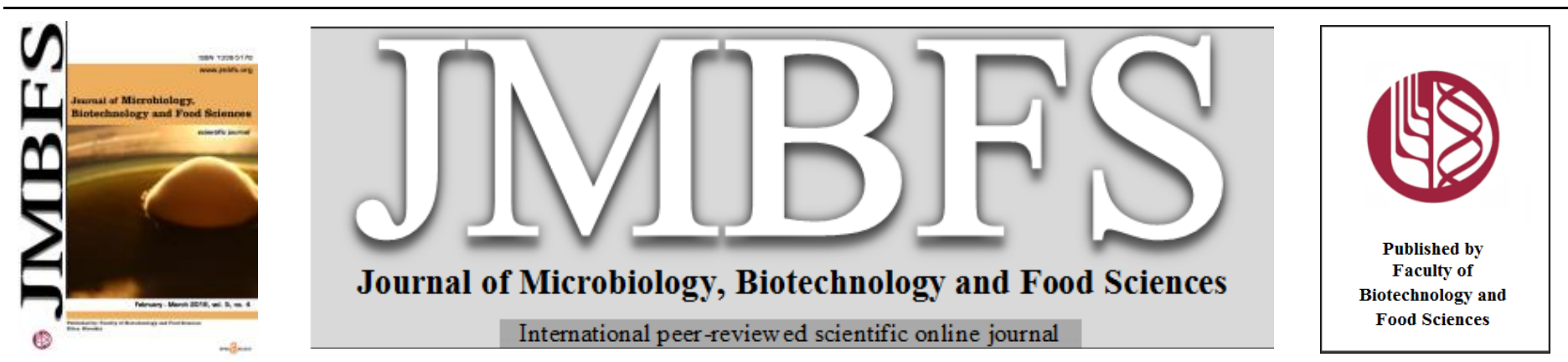

\title{
SURVIVAL OF SELECTED BACTERIA OF ARCOBACTER GENUS IN DISINFECTANTS AND POSSIBILITY OF ACQUIRED SECONDARY RESISTANCE TO DISINFECTANTS
}

\author{
David Šilha*, Lucie Šilhová, Jarmila Vytřasová, Iveta Brožková, Marcela Pejchalová
}

Address(es): Ing. David Šilha, Ph.D.,

Department of Biological and Biochemical Sciences, Faculty of Chemical Technology, University of Pardubice, Studentská 573, 53210 Pardubice, Czech Republic, phone number: +420 466037765 .

*Corresponding author: david.silha@upce.cz

doi: 10.15414/jmbfs.2016.5.4.326-329

\section{ARTICLE INFO}

Received 29. 1. 2015

Revised 4. 6. 2015

Accepted 29. 10. 2015

Published 1. 2. 2016

Regular article OPEN $\partial_{\text {ACCESS }}$

\begin{abstract}
Bacteria of the genus Arcobacter are today feared pathogens and represent a true threat, particularly in the form of alimentary infections. This study presents information on the inhibitory concentrations of selected disinfectant agents frequently applied in the Czech Republic, and particularly in the food industry for sanitation. The results of the study indicate that total inactivation of tested arcobacters are mostly at concentration of 5.0-15.0\% in case of Desprej-disinfectant, 10.0-15.0\% in case of Incidur-disinfectant, respectively 1.0$15.0 \%$ Guaa Profi Pool-disinfectant. Nevertheless, it has been confirmed that there is a real risk for secondary resistance of arcobacters to emerge in relation to certain decontaminants. Through repeated passages of arcobacters in a medium with low concentration of the disinfectant, we increased their primary resistance to the Incidur disinfectant to 1.5-3.5x (depending on species or origin). In the case of Desprej, the primary resistance of arcobacters to the substance was increased to even 1.5-5x. The emergence of resistance to antimicrobial substances is a worldwide problem. Potential acquisition of resistance (secondary resistance) in case of Arcobacter spp. was confirmed in this study for the first time in the Czech Republic.
\end{abstract}

\section{INTRODUCTION}

Arcobacters were first isolated by Ellis in 1977 from aborted cattle foetuses (Ellis et al., 1977). The genus Arcobacter was established in 1991 (Vandamme and De Ley, 1991; Vandamme et al., 1992). These bacteria are Gram-negative, slender, spiral-shaped rods, and are classified in the family Campylobacteraceae along with the genus Campylobacter (Snelling et al., 2006). Arcobacters nevertheless differ from campylobacters in their growth conditions. Arcobacters grow optimally at temperatures of $15-30^{\circ} \mathrm{C}$ in the presence of oxygen (Wesley $\boldsymbol{e}$ al., 2000). In recent years, a number of new species have been classified into this genus, which currently includes 20 species. Many species have been isolated in particular from poultry (Atabay $\boldsymbol{e t}$ al., 1998), meat, human faeces and faeces of animals suffering from gastrointestinal tract diseases and from aborted cattle foetuses (A. butzleri, A. cryaerophilus, A. skirrowii, A. cibarius, A. thereius and A. trophiarum). Recently, however, isolation from the maritime environment also has been very common and several new species of arcobacters were described from maritime and water environment (A. marinus, A. molluscorum, A. mytili, A. ellisii, A. bivalviorum and A. venerupis) (Collado et al., 2009; Levican et al., 2012a,b). Other representatives include $A$. defluvii from sewage water, $A$. nitrofigilis and $A$. halophilus from salt marshes (Levican et al., 2012a) and newly classified representatives A. cloaceae, A. suis (Levican et al., 2012b), A. anaerophilus (Jyothsna et al., 2013), A. ebronensis and A. aquimarinus (Levican et al., 2014)

Antiseptics and disinfectants are used extensively in modern food and veterinary production. They are an essential part of infection control practices and aid in the prevention of clinical and subclinical diseases (McDonnell and Russell, 1999). Environmental surfaces, especially those in kitchen and bathrooms, frequently have been found to be contaminated with potential pathogens, including enteric Gram-negative bacteria (Rutala et $\boldsymbol{a l}$., 2000). Due to the pathogenicity of arcobacters, it is necessary to establish disinfection procedures correctly, especially in the food industry but also in other operations, hospitals and households. Recently, some authors have evidenced that this organisms can survive on the surfaces of equipment in industry. Food constitutes an excellent environment for the growth of microorganisms, and their adhesion to food production equipment is very dangerous and frequently described (Khajavi $\boldsymbol{e t ~ a l . ,}$ 2007; Fazlara and Ekhtelat, 2012). The threat of various alimentary infections leads to more frequent use of disinfectants, which arouses fear as to the possibility for emerging bacterial resistance. Recommended measures to reduce food contamination include biosecurity and hygiene at the farm, slaughterhouse, food industry and kitchen surfaces (McDonnell and Russell, 1999). A disinfectant agent is defined as a compound reducing the numbers of viable cells of a certain group of microorganisms (not spores). Disinfectants are usually applied to inanimate objects and surfaces (McDonnell and Russell, 1999). There exists a whole range of various disinfectant agent groups. Disinfectants based on a content of surfactants such as quaternary ammonium compounds (QAC) are also widely used in the food industry. They are effective against a broad array of bacteria and can be applied at a wide range of temperatures (Moretro et al., 2012). Frequent industrial use of QAC-based disinfectants can lead to the development of strains resistant to these substances. Resistance can be achieved by mutation, acquisition of new genetic information, by horizontal gene transfer, expression of previously silent genes, growth in a biofilm, and other (Chapman et al., 2003). Thus far, however, very little information on the possibility of emerging QAC resistance in Gram-negative bacteria has been published (Sidhu et al., 2002).

This study deals with survival of bacteria of the Arcobacter genus in several selected disinfectants commonly applied in the Czech Republic, and especially in food production plants and laboratories. The study also points out the real possibility for the emergence of secondary resistance in arcobacters to selected disinfectants. To our knowledge, this subject has not yet been described in literature, it would be useful also to develop the topic of secondary resistance's acquirement in other studies.

\section{MATERIAL AND METHODS}

Bacterial cultures and cultivation

The cultures A. cryaerophilus CCM 3934 from the Czech Collection of Microorganisms in Brno, Arcobacter butzleri CCUG 30484 from the Culture Collection, University of Göteborg, Göteborg, Sweden; and Arcobacter defluvii LMG 25694 from the Belgian Co-ordinated Collection of Microorganisms, University of Ghent, Ghent, Belgium were used. The cultures A. butzleri 2013/29 and A. cryaerophilus 2013/23 are isolates from food of animal origin and were used as wild-type strains in this study which were isolated during our previous study (Šilha et al., 2015). All cultures were cultivated on Mueller-Hinton agar 
(MHA, Himedia, Mumbai, India) under aerobic conditions for $48 \mathrm{~h}$ at $30{ }^{\circ} \mathrm{C}$ and then stored at $4{ }^{\circ} \mathrm{C}$. Bacterial suspensions were prepared at a density of $\sim 10^{8}$ cfu. $\mathrm{ml}^{-1}$ in physiological solution and subsequently, serial decimal dilutions were prepared for other experiments in physiological solution.

\section{Applied disinfectants}

Several commercial disinfectants were chosen for testing in this study. The active ingredients and the used dilution for the tested products were as follows:

Guaa-Profi Pool (Guapex, Brno, Czech Republic): non-chlorinated disinfectant for water, active ingredients - quaternary ammonium compounds (QAC), concentrations used 0.1-15\%; Incidur (Ecolab Hygiene, Brno, Czech Republic): disinfectant for surfaces and areas, active ingredients - glyoxal and glutaraldehyde, concentrations used $0.1-15 \%$;

Desprej (Bochemie Group, Bohumín, Czech Republic): disinfectant for surfaces and areas, active ingredient - quaternary ammonium compounds (QAC), ethanol, isopropanol, concentrations used $0.1-15 \%$.

The disinfectants were stored in the dark at room temperature and prepared used dilution in sterile Mueller-Hinton broth. All products were tested within the specified use-life.

\section{Determining survival of Arcobacter spp. in disinfectants}

The survival of arcobacters in selected disinfectants was determined by a suspension method in tubes (Wiegand et al., 2008). The range tested concentrations of the disinfectants (see figures 1-3) were prepared in tubes in Mueller-Hinton (MH) broth (HiMedia, Mumbai, India) and subsequently inoculated with $1 \mathrm{ml}$ of cell suspension with density $10^{6} \mathrm{cfu} \cdot \mathrm{ml}^{-1}$ (total volume of $10 \mathrm{ml})$. After stirring the volume (30 s), $100 \mu \mathrm{l}$ was spread onto Mueller-Hinton agar and cultivated $\left(30{ }^{\circ} \mathrm{C}, 48 \mathrm{~h}\right)$. Simultaneously, the survival of arcobacters after longer time exposure ( $30 \mathrm{~min}, 1 \mathrm{~h}, 6 \mathrm{~h}$ ) were tested, but arcobacters were already completely inhibited. Actual density in the initial suspension was determined by the cultivation method by inoculating the pertinent dilution onto Mueller-Hinton agar $\left(10^{2} \mathrm{cfu} \cdot \mathrm{ml}^{-1}\right)$. The dependence of the number of logarithm cfu. $\mathrm{ml}^{-1}$ and disinfectant concentrations was observed. After each concentration, it was determined whether the cells were actually dead or in viable-butnonculturable (VBNC) form. This was done by transferring the cell suspension in brain-heart infusion (BHI) broth (Himedie, Mumbai, Indie) under aerobic conditions for $48 \mathrm{~h}$ at $30{ }^{\circ} \mathrm{C}$. As a control for the cell density introduced into mixture of disinfectant and broth, processing was always determined according to description above (without effect of disinfectant). Each determination was performed in duplicate and the experiment was repeated three times. The data obtained were statistically analysed using the standard deviation of mean.

\section{Resistance of the bacteria to selected disinfectants}

The resistance of five selected arcobacters to the disinfectants Incidur and Desprej was determined. To test the potential for the emergence of secondary resistance, $100 \mu \mathrm{l}$ of appropriate cell suspension with density $10^{8} \mathrm{cfu} \cdot \mathrm{ml}^{-1}$ was inoculated into $9.9 \mathrm{ml}$ of a mixture of Mueller-Hinton broth $(\mathrm{pH} 7.4 \pm 0.1)$ and a particular concentration of the tested disinfectant (according to the Table 1). Actual density in the initial suspension was determined by the cultivation method by inoculating the pertinent dilution onto Mueller-Hinton agar $\left(10^{2} \mathrm{cfu}^{\left.-\mathrm{ml}^{-1}\right)}\right.$. Cultivation was performed at $30{ }^{\circ} \mathrm{C}$ for $48 \mathrm{~h}$. At the start of the experiment, the highest concentration of the disinfecting agent at which the given microorganisms can still survive $(48 \mathrm{~h})$ under these conditions was determined. After two-day cultivation, $100 \mu \mathrm{l}$ of this cell suspension was subsequently transferred to another test tube with the same concentration of the disinfectant in Mueller-Hinton broth (passaging) and continued in the same way (adjusted according to Mrozek 1967). After a total of five passages in the same concentration of disinfectant, $100 \mu \mathrm{l}$ of the suspension was transferred into mixture of Mueller-Hinton broth with a higher concentration of the same disinfectant and it was determined whether the microorganisms had adapted to this higher concentration (positive growth in the tube, acquired secondary resistance). Each determination was performed in duplicate and the experiment was repeated three times. The data obtained were statistically analysed using the standard deviation of mean.

\section{RESULTS AND DISCUSSION}

The survival of Arcobacter spp. was determined for selected chemical disinfectants commonly applied in the food industry. Knowing how to define bacterial resistance is important for practical users of disinfectants. The effectiveness of disinfectants depends, of course, on the process and means of their application (Sidhu et al., 2002). One of the disinfectants tested in this study was Guaa Profi Pool (Fig. 3). It can be stated that this disinfectant product has bactericidal effects already at very low concentrations in case of majority tested arcobacters. For example, A. defluvii LMG 25694 was already inactivated in concentration of $1.0 \%$. We tested lower concentration in this case of high susceptibility $(0.50 \%-\log$ cfu 2.37$)$ but this point is not displayed in Fig 2 . A concentration of $5.0 \%$ was determined to be the inhibitory concentration for $A$. cryaerophilus CCM 3934 during immediate inoculation (exposure time 30 s). For A. butzleri CCUG 30484, the inhibitory concentration was higher, concretely $7.0 \%$ during the same exposure time. However, isolate from food (A. butzleri 2013/23) seems to be the most resistant to this disinfectant (inhibitory concentration is $15.0 \%)$. A. cryaerophilus CCM 3934 is obviously one of the most sensitive tested arcobacters, inhibitory concentrations in Guaa Profi Pool, Desprej and Incidur disinfectant are 5.0\%, 5.0\%, resp. 10.0\%. Furthermore, $A$. butzleri 2013/23 (isolate from food) seems to be the most resistant of tested arcobacters to all disinfectants. The results of the survival in these disinfectants are presented in Fig 2. As no repeated growth occurred in the inhibited culture, even after further cultivation in an environment without the given substance (the cells were actually dead, not in VBNC form). Important fact is that the wild strains tested in this study were more resistant to tested disinfectants (see Fig 1-3) in comparison with strains from culture collections.

Table 1 Emergence of secondary resistance in selected strains of Arcobacter genus in disinfectants $(\mathrm{n}=3)$

\begin{tabular}{|c|c|c|c|c|c|c|}
\hline Disinfectant & Microorganism & $\begin{array}{c}\mathbf{R}_{\mathrm{p}^{-}} \\
\mathbf{M I C} \\
(\%)\end{array}$ & $\mathbf{N}$ & $\mathbf{M}$ & $\begin{array}{c}\mathbf{R}_{\mathrm{s}^{-}} \\
\mathbf{M I C} \\
(\%)\end{array}$ & $\begin{array}{c}\text { Multiple } \\
\text { increase } \\
\text { of } \mathbf{R}_{p}\end{array}$ \\
\hline \multirow{5}{*}{ Incidur } & $\begin{array}{l}\text { A. butzleri CCUG } \\
30484\end{array}$ & 0.2 & 5 & 3 & 0.3 & 1.5 \\
\hline & A. butzleri $2013 / 23$ & 0.1 & 5 & 3 & 0.2 & 2 \\
\hline & $\begin{array}{l}\text { A. cryaerophilus } \\
\text { CCM } 3934\end{array}$ & 0.2 & 5 & 3 & 0.3 & 1.5 \\
\hline & $\begin{array}{l}\text { A. cryaerophilus } \\
2013 / 29\end{array}$ & 0.2 & 5 & 1 & 0.25 & 1.25 \\
\hline & $\begin{array}{l}\text { A. defluvii LMG } \\
25694\end{array}$ & 0.1 & 5 & 5 & 0.35 & 3.5 \\
\hline \multirow{5}{*}{ Desprej } & $\begin{array}{l}\text { A. butzleri CCUG } \\
30484\end{array}$ & 0.2 & 5 & 15 & 1 & 5 \\
\hline & A. butzleri $2013 / 23$ & 0.2 & 5 & 6 & 0.4 & 2 \\
\hline & $\begin{array}{l}\text { A. cryaerophilus } \\
\text { CCM } 3934\end{array}$ & 0.1 & 5 & 8 & 0.5 & 5 \\
\hline & $\begin{array}{l}\text { A. cryaerophilus } \\
2013 / 29\end{array}$ & 0.2 & 5 & 16 & 1 & 5 \\
\hline & $\begin{array}{l}\text { A. defluvii LMG } \\
25694\end{array}$ & 0.1 & 5 & 3 & 0.15 & 1.5 \\
\hline
\end{tabular}

Legend: $\mathrm{N}$ - number of passages in Mueller-Hinton broth with the same concentration of the disinfectant; $\mathrm{M}$ - repetition number of $\mathrm{N} ; \mathrm{R}_{\mathrm{p}}-\mathrm{MIC}$ minimum inhibitory concentration - primary resistance; $\mathrm{R}_{\mathrm{s}}-\mathrm{MIC}$ - minimum inhibitory concentration - secondary resistance

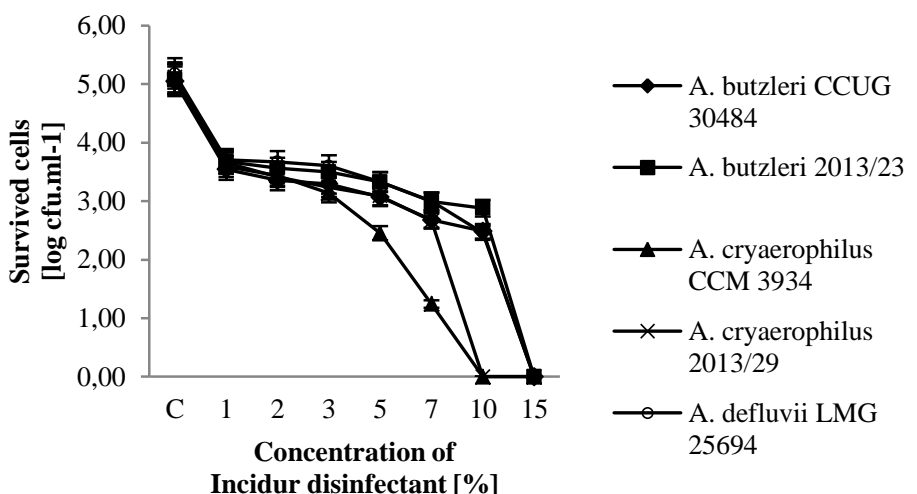

Figure 1 Survival of arcobacters in Incidur-disinfectant (exposure time $30 \mathrm{~s}$ ) determined by a plating method. Results are expressed as $\log _{10}$ of survived cfu.ml ${ }^{-1}$. Bars represent standard deviation of the mean $(n=3)$. C - control examination (without disinfectant) 

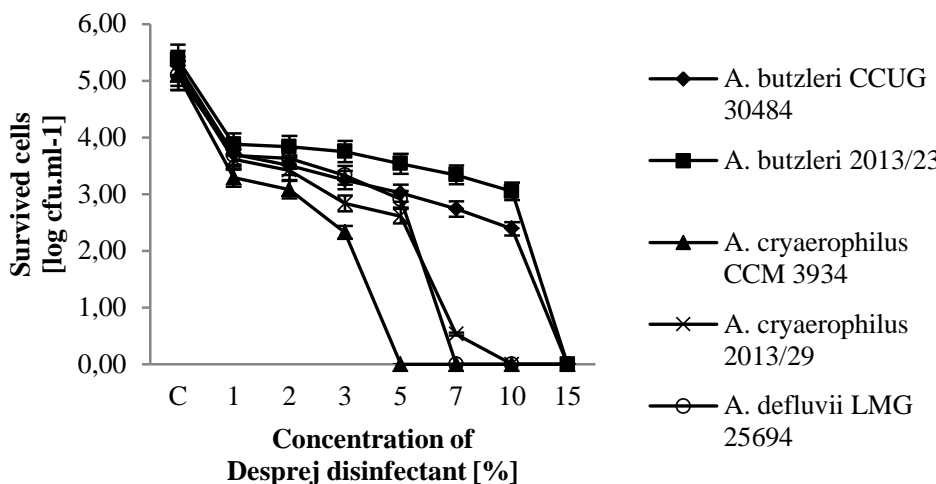

Figure 2 Survival of arcobacters in Desprej-disinfectant (exposure time $30 \mathrm{~s}$ ) determined by a plating method. Results are expressed as $\log _{10}$ of survived cfu.ml ${ }^{-1}$. Bars represent standard deviation of the mean $(n=3)$. C - control examination (without disinfectant).
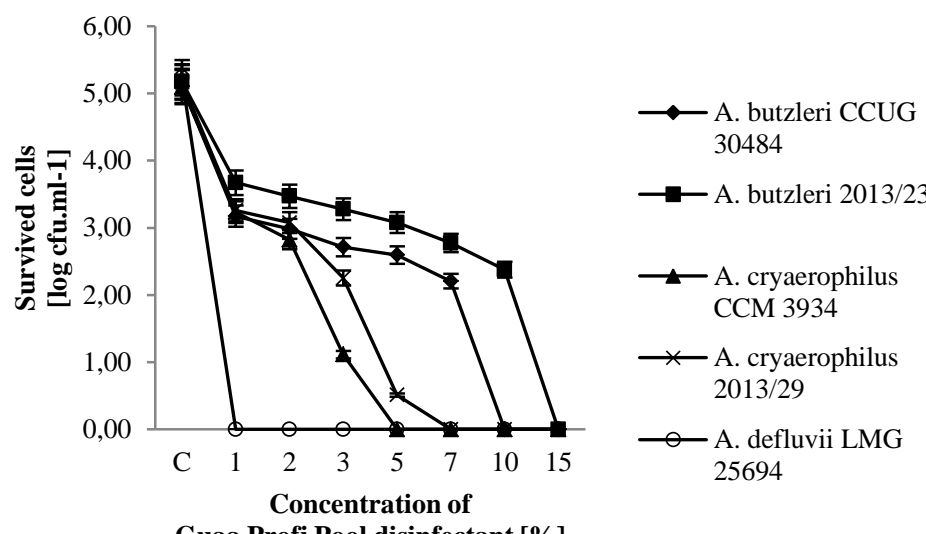

Guaa Profi Pool disinfectant [\%]

Figure 3 Survival of arcobacters in Guaa Profi Pool-disinfectant (exposure time $30 \mathrm{~s}$ ) determined by a plating method. Results are expressed as $\log _{10}$ of survived cfu. $\mathrm{ml}^{-1}$. Bars represent standard deviation of the mean $(n=3) . C-$ control examination (without disinfectant).

The results have been indicated that arcobacters are more sensitive to all tested disinfectants than are other bacteria (e.g. Pseudomonas, data not shown). The notable sensitivity of arcobacters to many environmental influences has already been reported (Šilha $\boldsymbol{e t} \boldsymbol{a l}$., 2014). Arcobacters are closely related to Campylobacter spp., however, campylobacters are much more sensitive to many effects, e.g. $\mathrm{pH}$ values, growing in the range of $6.5-8.0$, in comparison with Arcobacter, for which growth in the range $\mathrm{pH} 8.0-8.5$ can be observed (Cervenka, 2007). In our study, similar sensitivity was obtained also in experiments with tested disinfectants. The species A. butzleri CCUG 30484 was more resistant to the disinfectant effects. Experiments with Gram-positive bacteria such as Staphylococcus aureus and Pseudomonas aeruginosa, however, indicated their significantly higher resistance (data not displayed in the publication) in comparison with arcobacters. Arcobacters are more susceptible to many effects than Gram-positive bacteria, e.g. S. aureus. This is explained by the fact that the resistance mechanism is more complex in Gram-negative bacteria due to the presence of both an internal and external membrane, and also by the important role played in this respect by the presence of a lipopolysaccharide layer (Helander et al., 1997; Brula and Cooteb, 1999).

Disinfectants are based on various active ingredients. For example, the antimicrobial effect of substances we tested, Guaa-Profi Pool and Desprej, is based on a content of quaternary ammonium compounds. In these disinfectants, there is a greater risk for the emergence of resistance in various bacteria. This fact has already been confirmed in many studies, particularly in relation to Grampositive bacteria of the genera Staphylococcus, Listeria, Lactobacillus, among others (Sidhu et al., 2002). Relatively little information has been published thus far about the occurrence of QAC-resistant Gram-negative bacteria in the food industry and pathogens related to food. Willingham et al. (1996) tested 350 bacterial chicken isolates in relation to their resistance to QAC, phenol and glutaraldehyde. They determined that ca $1 \%$ of strains were resistant to QACbased disinfectants (especially Enterobacter and Serratia spp.).

One of the most important requirements for disinfectants is their safe effectiveness at low concentrations and short exposure times. However, the decreasing concentrations must not go into the range of sub-lethal concentrations and thus contribute to the potential emergence of secondary resistance in the microorganisms (Pyle et al., 1994).

The results of testing the potential for emergence of secondary resistance in selected bacteria of the genus Arcobacter confirmed that adaptations to sub-lethal concentrations of disinfectants can in fact occur. These experiments were tested in case of Desprej and Incidur-disinfectant. The third applied disinfectant in this study (Guaa Profi Pool) was so effective against arcobacters that the possibility of secondary resistance was not observed. A. defluvii LMG 25694 was primarily resistant to the disinfectant Incidur at $0.1 \%$ concentration (exposure time $2 \mathrm{~d}$ ). With gradual passaging in low concentrations of the given substance at optimal cultivating temperature (as described above), the resistance was increased to a concentration of $0.35 \%$. The resistance was thus increased to $3.5 \mathrm{x}$ its original, primary level of resistance. The secondary resistance in case of A. butzler $2013 / 23$ (isolates from food) was a little bit higher than in case of cultural strain of A. butzleri (see Table 1). However, this trend has not been proven with $A$ cryaerophilus, both, cultural strain and isolate. In another tested disinfectant, Desprej, there was a more significant emergence of secondary resistance. For the strain A. cryaerophilus CCM 3934, in particular, there was an increase to 5.0x the primary resistance. The results of increase from primary resistance during passaging in a disinfecting agent are presented in Table 1. Evidently, we cannot compare the results from the determination of inhibition concentrations with the results of secondary resistance. These methods are different under different conditions (inhibitory concentrations - the time of exposure $30 \mathrm{~s}$; the exposure time for determination of secondary resistance $48 \mathrm{~h}$ - cultivation in MuellerHinton broth).

The discussion in case of acquired secondary resistance is complicated because of limited information about this topic in literature. To our knowledge, there are no previous data for possibility of secondary resistance in case of Arcobacter spp. Previously, Růžičková and Majerníková (1999) have already described a similar trend for the emergence of secondary resistance in Gram-negative bacteria under the effect of the material Antibacteric-P (a QAC). In that study, the resistance of $E$. coli bacteria was increased even by as much as $2,917 \mathrm{x}$, and by $32 \mathrm{x}$ in Citrobacter spp.

Further studies are planned to examine resistance also in other species of arcobacters, and in relationship to several additional influences and conditions.

\section{CONCLUSION}

The genus Arcobacter is closely related to the well-known human pathogen Campylobacter jejuni. These bacteria are today dreadful pathogens and constitute a considerable threat, particularly in the form of alimentary infection. Environmental surfaces have been frequently found to be contaminated with pathogenic bacteria. The disinfection process is necessary precaution against these bacteria. Our results demonstrate that tested disinfectants have good activity against bacteria from the genus Arcobacter spp. The disinfectants were effective in a short time. The results indicate the wild strains of Arcobacter could be more resistant to disinfectant and other effects and it would be desirable to test more wild strains in future. However, the study shows the potential risk for secondary resistance of Arcobacter spp. to selected disinfectants. The emergence of resistance to antimicrobial substance is a worldwide problem and this topic is described in case of Arcobacter spp. for the first time, to our knowledge.

Acknowledgments: This study was supported by a grant project of the Faculty of Chemical Technology, University of Pardubice, Czech Republic - SGFChT $07 / 2015$.

\section{REFERENCES}

ATABAY, H. I., CORRY, J. E. L., ON, S. L. W. 1998. Diversity and prevalence of Arcobacter spp. in broiler chickens. Journal of Applied Microbiology, 84(6), 1007-1016. http://dx.doi.org/10.1046/j.1365-2672.1998.00437.x

BRULA, S., COOTEB, P. 1999. Preservative agents in foods mode of action and microbial resistence mechanisms. International Journal of Food Microbiology, 50(1-2), 1-17. http://dx.doi.org/10.1016/s0168-1605(99)00072-0

CERVENKA, L. 2007. Survival and inactivation of Arcobacter spp., a current status and future prospect. Critical Reviews in Microbiology, 33(2), 101-108. http://dx.doi.org/10.1080/10408410701364497

CHAPMAN, J. S. 2003. Disinfectant resistance mechanisms, cross-resistance, and co-resistance. International Biodeterioration and Biodegradation, 51(4), 271-276. http://dx.doi.org/10.1016/s0964-8305(03)00044-1

COLlADO, L., CLEENWERCK, I., VAN TRAPPEN, S., DE VOS, P. FIGUERAS, M. J. 2009. Arcobacter mytili sp. nov., an indoxyl acetatehydrolysis-negative bacterium isolated from mussels. International Journal of Systematic and Evolutionary Microbiology, 59(6), 1391-1396. http://dx.doi.org/10.1099/ijs.0.003749-0

ELLIS, W. A., NEILL, S. D., O'BRIEN, J. J., FERGUSON, H. W., HANNA, J. 1977. Isolation of Spirillum/Vibro-like organismsfrom bovine fetuses. Veterinary Record, 100(21), 451-452. http://dx.doi.org/10.1136/vr.100.21.451 
FAZLARA, A., EKHTELAT, M. 2012. The disinfectant effects of benzalkonium chloride on some important foodborne pathogens. American-Eurasian Journal of Agricultural and Environmental Sciences, 12(1), 23-29.

JYOTHSNA, T. S., RAHUL, K., RAMAPRASAD, E. V. V., SASIKALA, C., RAMANA, C. V. 2013. Arcobacter anaerophilus sp. nov., isolated from an estuarine sediment and emended description of the genus Arcobacter. International Journal of Systematic and Evolutionary Microbiology, 63(12), 4619-4625. http://dx.doi.org/10.1099/ijs.0.054155-0

KHAJAVI, R., SATTARI, M., ASHJARAN, A. 2007. The antimicrobial effect of benzalkonium chloride on some pathogenic microbes observed on fibers of acrylic carpet. Pakistan Journal of Biological Sciences, 10(4), 598-601. http://dx.doi.org/10.3923/pjbs.2007.598.601

LEVICAN, A., COLLADO, L., AGUILAR, C., YUSTES, C., DIÉGUEZ, A. L., ROMALDE, J. L., FIGUERAS, M. J. 2012a. Arcobacter bivalviorum sp. nov. and Arcobacter venerupis sp. nov., new species isolated from shellfish. Systematic and Applied Microbiology, 35(3), 133-138. http://dx.doi.org/10.1016/j.syapm.2012.01.002

LEVICAN, A., COLLADO, L., FIGUERAS, M. J. 2012b Arcobacter cloaceae sp. nov. and Arcobacter suis sp. nov., two new species isolated from food and sewage. Systematic and Applied Microbiology, 36(1), 22-27. http://dx.doi.org/10.1016/j.syapm.2012.11.003

HELANDER, I. M., MATTILA-SANDHOLM, T. M., VONWRIGHT, A. 1997.

Potential of lactic acid bacteria and novel antimicrobials against gram-negative bacteria. Trends in Food Science and Technology, 8(5), 146-150. http://dx.doi.org/10.1016/s0924-2244(97)01030-3

MCDONNELL, G., RUSSELL, A. D. 1999. Antiseptics and disinfectants: Activity, action, and resistence. Clinical Microbiology Reviews, 12(1), 147-179.

MØRETRØ, T., HEIR, E., NESSE, L. L., VESTBY, L. K., LANGSRUD, S 2012. Control of Salmonella in food related environments by chemical disinfection. Food Research International, 45(2), 532-544. http://dx.doi.org/10.1016/j.foodres.2011.02.002

MROZEK, H. 1967. Untersuchungen zum problem der resistenzentwicklungen gegenueber desinfektionsmitteln. Brauwissenschaft, 20, 225-234.

PYLE, B. H., WATTERS, S. K., MCFETERS, G. A. 1994. Physiological espects of disinfection resistence in Pseudomonas cepacia. Journal of Applied Bacteriology, $\quad 76(2), \quad 142-148 . \quad$ http://dx.doi.org/10.1111/j.1365-

2672.1994.tb01609.x

RUTALA, W. A., BARBEE, S. L., AGUIAR, N. C., SOBSEY, M. D., WEBER, D. J. 2000. Antimicrobial activity of home disinfectants and natural products against potential human pathogens. Infection Control and Hospital Epidemiology, 21(1), 33-38. http://dx.doi.org/10.1086/501694

RŮŽIČKOVÁ, A., MAJERNÍKOVÁ, I. 1999. Secondary resistence of microorganisms against decontamination agent Antibacteric-P. Bulletin of Food Research, 38(2), 67-83.

SIDHU, M. S., SØRUM, H., HOLCK, A. 2002. Resistance to quaternary ammonium compounds in food-related bacteria. Microbial Drug Resistance, 8(4), 393-399. http://dx.doi.org/10.1089/10766290260469679

SNELLING, W. J., MATSUDA, M., MOORE, J. E., DOOLEY, J. S. G. 2006 Under the microscope: Arcobacter. Letters in Applied Microbiology, 42(1), 7-14. http://dx.doi.org/10.1111/j.1472-765x.2005.01841.x

ŠILHA, D., HRUŠKOVÁ, L., BROŽKOVÁ, I., MOŤKOVÁ, P., VYTŘASOVÁ, J. 2014. Survival of selected bacteria from the genus Arcobacter on various metallic surfaces. Journal of Food and Nutrition Research, 53(3), 217-223.

ŠILHA, D., ŠILHOVÁ-HRUŠKOVÁ, L., VYTŘASOVÁ, J. 2015. Modified isolation method of Arcobacter spp. from different environmental and food samples. Folia Microbiologica, 60 (6), 515-521. http://dx.doi.org/10.1007/s12223-015-0395-x
VANDAMME, P., DE LEY, J. 1991. Proposal of a new family, Campylobacteraceae. International Journal of Systematic Bacteriology, 41(3), 451-455. http://dx.doi.org/10.1099/00207713-41-3-451

VANDAMME, P., VANCANNEYT, M., POT, B., MELS, L., HOSTE, B., DEWETTINCK, D., VAN DEN BORRE, C., HIGGINS, R., HOMMEZ, J., KERSTERS, K., BUTZLER, J. P., GOOSSENS, H. 1992. Polyphasic taxonomic study of of the emended genus Arcobacter with Arcobacter butzleri comb. nov. and Arcobacter skirrowii sp. nov., an aerotolerant bacterium isolated from veterinary specimens. International Journal of Systematic Bacteriology, 42(3), 344-356. http://dx.doi.org/10.1099/00207713-42-3-344

WESLEY, I. V., WELLS, S. J., HARMON, K. M., GREEN, A., SCHROEDERTUCKER, L., GLOVER, M., SIDDIQUE, I. 2000. Fecal shedding of Campylobacter and Arcobacter spp. in dairy cattle. Applied and Environmental Microbiology, 66(5), 1994-2000. http://dx.doi.org/10.1128/aem.66.5.19942000.2000

WIEGAND, I., HILPERT, K., HANCOCK, R. E. W. 2008. Agar and broth dilution methods to determine the minimal inhibitory concentration (MIC) of antimicrobial substances. Nature Protocols, 3(2), 163-175. http://dx.doi.org/10.1038/nprot.2007.521

WILLINGHAM, E. M., SANDER, J. E., THAYER, S. C., WILSON, J. L. 1996. Investigation of bacterial resistence to hatchery disinfections. Avian Diseases, 40(3), 510-515. http://dx.doi.org/10.2307/1592258 